\title{
Quality of life and characteristics of diabetic patients
}

\author{
Karina Corrêa ${ }^{1}$ \\ Giovana Renata Gouvêa ${ }^{1}$ \\ Marco Antonio Viera da Silva ${ }^{1}$ \\ Rosana de Fátima Possobon ${ }^{1}$ \\ Luis Fernando de Lima Nunes Barbosa ${ }^{1}$ \\ Antonio Carlos Pereira ${ }^{1}$ \\ Luciane Guerra Miranda ${ }^{1}$ \\ Karine Laura Cortellazzi ${ }^{1}$
}

${ }^{1}$ Faculdade de Odontologia de Piracicaba, Unicamp. Av. Limeira 901, Areião. 13414903 Piracicaba SP Brasil. kacorrea82@gmail.com

\begin{abstract}
This study aimed to assess the association between quality of life and clinical and sociodemographic variables in type 2 diabetes patients, after they had started treatment in Primary and Specialized Health Care. This is an analytical cross-sectional study with a sampling of diabetic patients from Primary $(n=385)$ and Specialized $(n=385)$ Health Care. The dependent variable, quality of life, was evaluated by the Diabetes Quality of Life Measure - Brazil. Clinical and sociodemographic data were collected. Bivariate analysis by chi square test tested the association between the dependent variable with the independent ones. Next, we performed an analysis of multiple logistic regression. In Specialized Health Care, individuals who practice physical activity had less chance of having worse quality of life and those with less time of diagnosis presented higher chance of worse quality of life. In Primary Health Care, those who performed diets and presented glycated hemoglobin $\leq 7 \%$ had less chance of having worse quality of life. Women presented higher chances of worse quality of life than men. We concluded that with exception to the time of diagnosis and sex, other variables that influenced quality of life of diabetics were modifiable factors (glycated hemoglobin, alimentary diet and physical activity).
\end{abstract}

Key words Diabetes Mellitus, Quality of life, Chronic diseases, Health Care 


\section{Introduction}

Higher longevity of the population, along with changes in lifestyle, especially regarding sedentary lifestyle and alteration in feeding patterns, contribute to the growth of the risk profile to chronic diseases such as diabetes mellitus (DM). The prevalence of this disease has risen dramatically, and represents an important public health problem in countries of Latin America ${ }^{1}$.

In developing countries, the rise of diabetes occurred in all age groups. In the group of 45 to 64 years, the prevalence will be tripled until 2030 and doubled on the age groups 20 to 44 years and above 65 years ${ }^{2}$.

According to the Brazilian Society of Diabetes $^{3}$, there are currently above 12 million carriers of the disease. Type 2 diabetes patients (DM2) represent $90 \%$ to $95 \%$ of cases, most of them being overweight or obese. Despite ocurring in any age group, in general, DM2 is diagnosed in patients aged above 40 years ${ }^{3}$. It is important to highlight that diabetes have high morbimortality, being the main causes of death, renal failure, amputation of a lower limb, blindness and cardiovascular disease, including coronary diseases and cerebrovascular accident ${ }^{4}$.

Studies indicate that the quality of life (QOL) of patients with DM is lower than that of those without the disease, and the aspects involved in this relation are not yet totally known. It is noteworthy that some variables such as type of DM, use of insulin, age, complications, social level, psychological factors, ethnicities, education, knowledge on the disease, type of assistance, among others, may interfere in the QOL of these patients ${ }^{5,6}$.

Improvements in the quality of assistance are a concern in world public health, since it has important consequences on the success of treatments and on reduction of damages ${ }^{7}$. Under that perspective, one of the actions of the Ministry of Health was the Plan for the Reorganization of Care for Arterial Hypertension and Diabetes, which created guidelines and goals for restructuring and enlarging the resolutive assistance and quality for carriers of these pathologies within the public health services network ${ }^{8}$. The referral for other levels of the health care system was stablished (within the own municipal area and neighboring ones) for those in need of specialized or hospital care ${ }^{9}$. Thus, the importance of higher integration between basic and special- ized units of SUS is emphasized ${ }^{10}$. Despite the negative impact of diabetes in its carriers quality of life being recognized, as well as with the presence of many variables involved in that process, studies that reveal which disease factors influence QOL are scarce. Therefore, facing the importance that DM has been gathering in the scenery of the world's public health care, studies that aim to identify that relation are providential.

Therefore, this study aimed to assess the association between quality of life and clinical and sociodemographic variables in type 2 diabetes patients, following the start of their treatments on Primary and Specialized Health Care in the city of Piracicaba, São Paulo, Brazil.

\section{Material and methods}

\section{Study type and location}

Analytical cross-sectional study performed in the city of Piracicaba, São Paulo, Brazil. The city is located at $160 \mathrm{Km}$ from the state's capital with an estimated population of 385,287 inhabitants, distributed throughout 63 neighborhoods ${ }^{11}$.

\section{Universe of study}

This study was conducted in the Specialized Health Care and in 12 Family Health Units (FHU) with patients aged between 25 and 90 years, between November, 2012, and September, 2013.

The Specialized Health Care functions as the diabetes reference service in the city and had a population of 1,312 users. A total of 4,213 diabetic patients was registered and monitored by the Family Health Units.

From the total of 46 USF implanted in the city, 17 had no physicians on the team (due to the lack of this professional in the city's public health care network) and therefore were not selected, because it would impair the referral of patients. From the 29 Units left, the 12 USF in which there was a specific day for care of diabetic patients were chosen to facilitate data collection and performance of interviews, considering the number of subjects of the sampling.

Type 2 diabetes patients older than 18 years under monitoring of Primary or Specialized Health Care for at least 12 months were included, except pregnant women and individuals with mental or neurological disorders. 


\section{Sampling}

A sampling number of 385 volunteers was calculated for each group, considering a confidence interval of $95 \%$ and sampling error of $5 \%$, being the proportion of 0.50 (50\% of the same answer to any question in the survey form) a calculation criteria.

\section{Collection of clinical and sociodemographic data}

The clinical (time of diagnosis, remedies in use, fasting glycemia last values, glycated hemoglobin last values, body mass index (BMI) and presence of disease complications) and sociodemographical (gender, age, education and marital status) data were collected from the patients' medical record.

\section{Application of the questionnaire Diabetes Quality Of Life Measure (DQOL-Brazil)}

It is a validated instrument, whose objective is to measure the subjective individual perception of the quality of life, such as impact, satisfaction and social concern related to DM. It is capable of determining changes after a therapeutic intervention, be it educational or pharmacological ${ }^{12}$. It was developed by the Diabetes Control and Complications Trial (DCCT) group, originally in English, for patients with type 1 diabetes and, later, used also to type 2 diabetes, being guided for application on adolescents and adults, under different types of diabetes treatments ${ }^{13,14}$.

The DQOL-Brazil contains 44 multiple choice questions organized under four domains: satisfaction (15 questions), impact (18 questions), social/vocational concerns (7 questions), and diabetes-related concerns (4 questions). The answers are organized in a 5 points Likert scale. The satisfaction is distributed in an intensity scale ( 1 = very satisfied; 2 = quite satisfied; $3=$ medium satisfied; 4 = little satisfied; 5 = not satisfied). The answers for the domains of concerns and impact are distributed in a frequency scale $(1=$ never; $2=$ almost never; $3=$ sometimes; $4=$ almost always; 5 = always). That way, the closer from 1 the result is, the better the evaluation of quality of life $\mathrm{e}^{12,15}$.

The survey form was self applied, with supervision from the researcher in a reserved room, following the medical appointment. For subjects with reading difficulties, the questions were integrally read by the researcher, and the answer options were proposed to the patients in each question.

\section{Data analysis}

The quality of life was considered a dependent variable, dichotomized by the median in $\leq$ 2.32 (best QOL) and $>2.32$ (worst QOL) for the Specialized Health Care and $\leq 2.02$ (best QOL) and $>2.02$ (worst QOL) for the USF groups. On both groups, the worst quality was the category adopted as reference for dependent variable in the data analysis.

The independent variables were: sex (female and male), age (adults: $<65$ years and older adults: $\geq 65$ years), Body Mass Index - BMI (adequate weight, overweight and obesity), diabetes mellitus diagnosis time in years (dichotomized by the average in $\leq 13$ and $>13$ for Special Health Care and $\leq 05$ and $>05$ for the USF), last fasting glycemia value - considered the glycemic target suggested by the International Diabetes Federation $^{16}-(\leq 100 \mathrm{mg} / \mathrm{dl}$ and $>100 \mathrm{mg} / \mathrm{dl})$, last glycated hemoglobin value - considering the target considered by the Brazilian Society of Diabetes ${ }^{3}$ ( $\leq 7 \%$ and $>7 \%$ ), presence of complications (yes and no), performance of diet for diabetes (yes and no), practice of physical activity (yes and no), medication in use (solely oral anti-diabetic and insulin) and education in years of study ( $\leq$ 08 - incomplete elementary school and $>08-$ complete elementary school).

A descriptive analysis was performed by means of average, standard deviation, absolute and relative frequency. Student's t test was applied to compare the general quality of life score average and the respective domains between the studied groups. Then, a bivariate analysis by the chi-square test was performed to test the association between the dependent variable with the independent ones. Following, the variables that presented value of $\mathrm{p}<0.20$ were tested in the multiple logistic regression model with stepwise procedure. The Odds Ratio (OR) and the respective ranges of $95 \%$ confidence interval (CI) were estimated for the variables that remained in the model. All the statistic tests were performed by the SAS 9.2 program considering a significance level of $5 \%$.

\section{Ethical aspects}

This study was approved by the Ethic and Research Committee of the School of Odontology of Piracicaba - FOP/Unicamp. 


\section{Results}

In the Specialized Health Care sample there was a predominance of the female sex $(65.2 \%), 86.5 \%$ reported to have 8 or more years of study and $37.9 \%$ were older adults ( $\geq 65$ years), being that the age average in this group was 62 years (SD $=10.6$ ). As for the time of diagnosis of diabetes, $45.5 \%$ declared presence of the disease for over 13 years. Regarding BMI, most patients presented obesity $(60.6 \%)$, while $26.2 \%$ were overweight and only $13 \%$ within the adequate weight. We observed that $82.8 \%$ of the diabetics presented a last fasting glycemia above $100 \mathrm{mg} / \mathrm{dl}$ and $85.3 \%$ had the most recent value of glycated hemoglobin above $7 \%$. As for the non-medication treatments, $44.2 \%$ of the interviewed declared performing diet to control the diabetes and 28.3\% practiced physical activity. Regarding the medication in use, most $(94.8 \%)$ used insulin.

There was a significant difference between the averages of general score and of each domain of the DQOL-Brazil between the studied groups, being that the Specialized Health Care group presented the highest values and, consequently, worst quality of life (Table 1).

Only the variable physical activity, under the bivariate analysis, presented significant association with the worst quality of life for patients of Specialized Health Care (Table 2). Table 3 presents the variables that remained in the multiple logistic regression model. The individuals that practiced physical activity had less chance $(\mathrm{OR}=$ 0.49) of presenting quality of life worse than that of those who did not practice physical exercises. Those with diagnosis of diabetes mellitus for $\leq$ 13 years presented 1.52 times more chance of having worse quality of life than those with longer time of diagnosis.
By the bivariate analysis presented in $\mathrm{Ta}$ ble 4 , it can be observed that the variables sex, diet, glycated hemoglobin and medication had significant association with the worst quality of life for the patients from the USF. Female sex was a risk factor for the worst quality of life. On the other hand, performing diet, presenting glycated hemoglobin values $\leq 7 \%$ and making use of oral medication were protection factors from the worst quality of life.

Table 5 presents the variables that remained in the multiple logistic regression model. Individuals who performed diet $(\mathrm{OR}=0.33)$ to control diabetes and that presented glycated hemoglobin $\leq 7 \%(\mathrm{OR}=0.55)$ had less chance of having a worse quality of life. But female patients had 1.61 times more chance of presenting a worse quality of life than those of men within the scope of USF patients.

\section{Discussion}

The maintenance of a satisfactory metabolic control decreases risk of these complications to diabetes patient ${ }^{17,18}$. For it to occur, it is necessary that these individuals have access to quality health care services, which assure a continuous and integral assistance in the different complexity levels demanded for handling the disease ${ }^{19}$. It is clear that Primary Health Care does not depletes its therapeutic resources, referring a gigantic demand of patients to the Secondary Health Care, that many times acts in a reductionist fashion upon the individual, solely considering the disease.

The results of this study revealed certain homogeneity between the two groups regarding the sociodemographic data. There was a predominance of the female sex, corroborating with the

Table 1. Comparison between domains of the quality of life instrument of patients cared at the Specialized Health Care and in Family Health Units. Piracicaba, São Paulo, Brazil, 2013.

\begin{tabular}{lcccccccc}
\hline \multirow{2}{*}{\multicolumn{1}{c}{ Domains }} & \multicolumn{3}{c}{ Specialized Health Care } & \multicolumn{3}{c}{ Family Health Units } \\
\cline { 2 - 8 } & average & $\begin{array}{c}\text { standard } \\
\text { deviation }\end{array}$ & $\mathbf{9 5 \% C I}$ & average & $\begin{array}{c}\text { standard } \\
\text { deviation }\end{array}$ & $\mathbf{9 5 \% C I}$ & p-value \\
\hline Satisfaction & 2,67 & 0,73 & $2,60-2,74$ & 2,42 & 0,75 & $2,34-2,49$ & $<0,0001$ \\
Impact & 2,43 & 0,79 & $2,35-2,51$ & 2,10 & 0,76 & $2,03-2,18$ & $<0,0001$ \\
Social and vocational concerns & 1,50 & 0,69 & $1,43-1,57$ & 1,25 & 0,51 & $1,20-1,30$ & $<0,0001$ \\
Concerns related to diabetes & 2,68 & 1,09 & $2,57-2,79$ & 2,19 & 1,06 & $2,09-2,30$ & $<0,0001$ \\
General & 2,39 & 0,62 & $2,31-2,44$ & 2,08 & 0,58 & $2,01-2,13$ & $<0,0001$ \\
\hline CI = Confidence Interval
\end{tabular}


Table 2. Association between quality of life and clinical and sociodemographic variables of patients serviced in the Specialized Health Care. Piracicaba, São Paulo, Brazil, 2013.

\begin{tabular}{|c|c|c|c|c|c|c|c|}
\hline & \multicolumn{7}{|c|}{ Quality of life } \\
\hline & \multicolumn{2}{|c|}{ Worst } & \multicolumn{2}{|c|}{ Best } & \multirow[b]{2}{*}{ OR crude } & \multirow[b]{2}{*}{$95 \% \mathrm{CI}$} & \multirow[b]{2}{*}{ p-value } \\
\hline & $\mathrm{n}$ & $\%$ & $\mathrm{n}$ & $\%$ & & & \\
\hline \multicolumn{8}{|l|}{ Sex } \\
\hline Female & 125 & 49,80 & 126 & 50,20 & 1,05 & $0,69-1,60$ & 0,8928 \\
\hline Male & 65 & 48,51 & 69 & 51,49 & 1 & & \\
\hline \multicolumn{8}{|l|}{ Age } \\
\hline$<65$ years & 117 & 48,95 & 122 & 51,05 & 0,96 & $0,63-1,45$ & 0,9250 \\
\hline$\geq 65$ years & 73 & 50,00 & 73 & 50,00 & 1 & & \\
\hline \multicolumn{8}{|c|}{ Body Mass Index (IMC) } \\
\hline Adequate weight & 28 & 56,00 & 22 & 44,00 & 1 & & \\
\hline Overweight & 46 & 45,54 & 55 & 54,46 & 0,66 & $0,33-1,30$ & 0,2999 \\
\hline Obesity & 116 & 49,57 & 118 & 50,43 & 0,77 & $0,42-1,43$ & 0,5033 \\
\hline \multicolumn{8}{|c|}{ Time of diagnosis of Diabetes Mellitus } \\
\hline$\leq 13$ years & 112 & 53,33 & 98 & 46,67 & 1,42 & $0,95-2,13$ & 0,1074 \\
\hline$>13$ years & 78 & 44,57 & 97 & 55,43 & 1 & & \\
\hline \multicolumn{8}{|l|}{ Fasting glycemia } \\
\hline$\leq 100$ & 27 & 40,91 & 39 & 59,09 & 0,67 & $0,39-1,15$ & 0,1851 \\
\hline$>100$ & 161 & 50,79 & 156 & 49,21 & 1 & & \\
\hline \multicolumn{8}{|l|}{ Glycated hemoglobin } \\
\hline$\leq 7 \%$ & 22 & 39,29 & 34 & 60,71 & 0,63 & $0,35-1,13$ & 0,1551 \\
\hline$>7 \%$ & 165 & 50,61 & 161 & 49,39 & 1 & & \\
\hline \multicolumn{8}{|l|}{ Diabetes complications } \\
\hline With & 49 & 52,69 & 44 & 47,31 & 1,19 & $0,75-1,90$ & 0,5352 \\
\hline Without & 141 & 48,29 & 151 & 51,71 & 1 & & \\
\hline \multicolumn{8}{|l|}{ Diet } \\
\hline Yes & 77 & 45,29 & 93 & 54,71 & 0,75 & $0,50-1,12$ & 0,2047 \\
\hline No & 112 & 52,34 & 102 & 47,66 & 1 & & \\
\hline \multicolumn{8}{|l|}{ Physical activity } \\
\hline Yes & 41 & 37,61 & 68 & 62,39 & 0,52 & $0,33-0,81$ & 0,0060 \\
\hline No & 148 & 53,82 & 127 & 46,18 & 1 & & \\
\hline \multicolumn{8}{|l|}{ Medication } \\
\hline Oral & 6 & 30,00 & 14 & 70,00 & 0,42 & $0,16-1,12$ & 0,1216 \\
\hline Insulin & 184 & 50,41 & 181 & 49,59 & 1 & & \\
\hline \multicolumn{8}{|l|}{ Education } \\
\hline$\leq 8$ years of study & 165 & 49,55 & 168 & 50,45 & 1,06 & $0,59-1,90$ & 0,9614 \\
\hline$>8$ years of study & 25 & 48,08 & 27 & 51,92 & 1 & & \\
\hline
\end{tabular}

$\mathrm{OR}=$ Odds Ratio; $\mathrm{CI}=$ Confidence Interval.

Table 3. Multiple logistic regression for the worst quality of life of patients serviced in the Specialized Health Care. Piracicaba, São Paulo, Brazil, 2013.

\begin{tabular}{lccccc}
\hline & \multicolumn{5}{c}{ Worst Quality of life } \\
\cline { 2 - 5 } & $\mathbf{n}$ & $\%$ & Adjusted OR & 95\%CI & p-value \\
\hline Physical activity & 41 & 37,61 & 0,49 & $0,31-0,78$ & 0,0028 \\
$\quad$ Yes & 148 & 53,82 & 1 & & \\
$\quad$ No & & & & & \\
$\quad$ Time of diagnosis of Diabetes Mellitus & 112 & 53,33 & 1,52 & $1,01-2,29$ & 0,0448 \\
$\quad \leq 13$ years & 78 & 44,57 & 1 & & \\
$\quad>13$ years & & & & &
\end{tabular}

$\mathrm{OR}=$ Odds Ratio $\mathrm{CI}=$ Confidence Interval. 
Table 4. Association between quality of life and clinical and sociodemographic variables of patients cared by the Family Health Units. Piracicaba, São Paulo, Brazil, 2013.

\begin{tabular}{|c|c|c|c|c|c|c|c|}
\hline & \multicolumn{7}{|c|}{ Quality of life } \\
\hline & \multicolumn{2}{|c|}{ Worst } & \multicolumn{2}{|c|}{ Best } & \multirow[b]{2}{*}{ OR crude } & \multirow[b]{2}{*}{$95 \% \mathrm{CI}$} & \multirow[b]{2}{*}{ p-value } \\
\hline & $\mathbf{n}$ & $\%$ & $\mathbf{n}$ & $\%$ & & & \\
\hline \multicolumn{8}{|l|}{ Sex } \\
\hline Female & 138 & 52,47 & 125 & 47,53 & 1,59 & $1,03-2,45$ & 0,0468 \\
\hline Male & 50 & 40,98 & 72 & 59,02 & 1 & & \\
\hline \multicolumn{8}{|l|}{ Age } \\
\hline$<65$ years & 123 & 52,79 & 110 & 47,21 & 1,50 & $0,99-2,26$ & 0,0688 \\
\hline$\geq 65$ years & 65 & 42,76 & 87 & 57,24 & 1 & & \\
\hline \multicolumn{8}{|c|}{ Body Mass Index (IMC) } \\
\hline Adequate weight & 19 & 39,58 & 29 & 60,42 & 1 & & \\
\hline Overweight & 62 & 47,69 & 68 & 52,31 & 1,39 & $0,71-2,73$ & 0,4269 \\
\hline Obesity & 107 & 51,69 & 100 & 48,31 & 1,63 & $0,86-3,09$ & 0,1766 \\
\hline \multicolumn{8}{|c|}{ Time of diagnosis of Diabetes Mellitus } \\
\hline$\leq 05$ years & 102 & 50,00 & 102 & 50,00 & 1,10 & $0,74-1,65$ & 0,7003 \\
\hline$>05$ years & 86 & 47,51 & 95 & 52,49 & 1 & & \\
\hline \multicolumn{8}{|l|}{ Fasting glycemia } \\
\hline$\leq 100$ & 33 & 52,38 & 30 & 47,62 & 1,18 & $0,68-2,02$ & 0,6480 \\
\hline$>100$ & 155 & 48,29 & 166 & 51,71 & 1 & & \\
\hline \multicolumn{8}{|l|}{ Glycated hemoglobin } \\
\hline$\leq 7 \%$ & 91 & 43,33 & 119 & 56,67 & 0,55 & $0,36-0,85$ & 0,0084 \\
\hline$>7 \%$ & 87 & 58,00 & 63 & 42,00 & 1 & & \\
\hline \multicolumn{8}{|c|}{ Diabetes complications } \\
\hline With & 32 & 46,15 & 42 & 53,85 & 0,87 & $0,53-1,44$ & 0,6870 \\
\hline Without & 152 & 49,51 & 155 & 50,49 & 1 & & \\
\hline \multicolumn{8}{|l|}{ Diet } \\
\hline Yes & 63 & 39,38 & 97 & 60,63 & 0,52 & $0,34-0,78$ & 0,0025 \\
\hline No & 125 & 55,56 & 100 & 44,44 & 1 & & \\
\hline \multicolumn{8}{|l|}{ Physical activity } \\
\hline Yes & 34 & 45,33 & 41 & 54,67 & 0,84 & $0,51-1,39$ & 0,5846 \\
\hline No & 154 & 49,68 & 156 & 50,32 & 1 & & \\
\hline \multicolumn{8}{|l|}{ Medication } \\
\hline Oral & 139 & 46,03 & 163 & 53,97 & 0,59 & $0,36-0,97$ & 0,0481 \\
\hline Insulin & 49 & 59,04 & 34 & 40,96 & 1 & & \\
\hline \multicolumn{8}{|l|}{ Education } \\
\hline$\leq 8$ years of study & 162 & 48,07 & 175 & 51,93 & 0,78 & $0,43-1,44$ & 0,5247 \\
\hline$>8$ years of study & 26 & 54,17 & 22 & 45,83 & 1 & & \\
\hline
\end{tabular}

$\mathrm{OR}=$ Odds Ratio; $\mathrm{CI}=$ Confidence Interval.

results of the study Vigilance of Risk Factors and Protection for Chronic Diseases by Telephone Inquiry (VIGITEL) ${ }^{20}$, which revealed that women lead the number of diabetes cases. The female prevalence might be related to the inclination of women in being more attendant to health services, favoring the diagnosis of the disease ${ }^{21}$.

Clinical data such as glycated hemoglobin value, insulin use and obesity, suggest, as it is ex- pected, that patients remitted to the Secondary Health Care have more difficulty in maintaining metabolic control. The cases that require more complex schemes are, in general, monitored by the Specialized Health Care ${ }^{22}$. Possibly, this justifies the worst quality of life perception for this group (values obtained in the DQOL-Brazil), both in the average of each domain, as in the general score. 
Table 5. Multiple logistic regression for the worst quality of life of patients serviced in the Family Health Units. Piracicaba, São Paulo, Brazil, 2013.

\begin{tabular}{|c|c|c|c|c|c|}
\hline & \multicolumn{5}{|c|}{ Worst Quality of life } \\
\hline & $\mathbf{n}$ & $\%$ & Adjusted OR & $95 \% \mathrm{CI}$ & p valor \\
\hline \multicolumn{6}{|l|}{ Diet } \\
\hline Yes & 63 & 39,38 & 0,331 & $0,331-0,786$ & 0,0023 \\
\hline No & 125 & 55,56 & 1 & & \\
\hline \multicolumn{6}{|c|}{ Glycated hemoglobin } \\
\hline$\leq 7 \%$ & 91 & 43,33 & 0,557 & $0,361-0,859$ & 0,0081 \\
\hline$>7 \%$ & 87 & 58,00 & 1 & & \\
\hline \multicolumn{6}{|l|}{ Sex } \\
\hline Female & 138 & 52,47 & 1,610 & $1,018-2,547$ & 0,0419 \\
\hline Male & 50 & 40,98 & 1 & & \\
\hline
\end{tabular}

$\mathrm{OR}=$ Odds Ratio; $\mathrm{CI}=$ Confidence Interval.

Furthermore, in the group referring to Special Care, the results showed that the individuals diagnosed with DM type $2 \leq 13$ years presented less chance of having a worse quality of life than those with more time of diagnosis. Probably, for having less time of adaptation with the disease and its treatment, the individuals with less time of diagnosis suffer with more immediate repercussions, such as difficulty in accepting the treatment with applications of insulin, self glycemic monitoring, alimentary restriction, possible episodes of hypoglycemia, among other conditions related to the illness and its treatment. According to Faria et al. ${ }^{23}$, the longer time of diagnosis of DM type 2 result in higher knowledge on the disease, as well as better understanding and handling of the therapeutic scheme. Educative interventions destined to facilitate the development of specific skills to face diabetes may improve the quality of life of patients carrying this disease ${ }^{24}$.

Diabetes type 2 , in general, reveals itself in a stage of life in which the individual already has fairly consolidated habits ${ }^{25}$, being important to perform educative actions and discussion groups so to acquire knowledge and skills on the daily self-care necessary to handle the disease $e^{4}$. Considering the complexity of its treatment, education on diabetes is the cornerstone for handling and controlling the disease, so that patients can achieve or preserve their quality of life ${ }^{26}$.

For the specialized care group, the results indicated that the patients who practiced physical activities had less chance of having worst QOL. Bennett et al. ${ }^{27}$ concluded that the best physical fitness intervened positively in the health-related quality of life related (HRQOL) of people with type 2 diabetes. In another study, Daniele et al. ${ }^{28}$, concluded that the sedentary diabetes patients presented the worst QOL. According to SBD Brazilian Society of Diabetes ${ }^{3}$, the physical exercise acts specifically on the insulin resistance besides acting on the reduction of the body weight that, on its own, reduces the risk of $\mathrm{DM} 2^{3}$.

Regarding the PSF group, the results of this study showed that, despite women attending more to health services, they had more chance of having a worse quality of life. This data corroborates with the study of Penckofer et al. ${ }^{29}$ that showed that the overload of responsibility towards support for the family is a factor that contributes to the non effectuation of the selfcare. Krug et al. ${ }^{30}$ found that marriage and care of children made women stop performing physical activity. Yet, individuals who presented glycated hemoglobin $\leq 7 \%$ had less chance of presenting worst quality of life. Goddijn et al. ${ }^{31}$ investigated the association between the improvement of the glycemic control (HbAlc less than $8 \%$ ) and the quality of life in type 2 diabetic patients during 1 years of treatment and showed positive association between these variables. A metanalysis study demonstrated that reductions above $0.3 \%$ of the glycated hemoglobin are clinically beneficial for controlling diabetes and, as consequence, improved the QOL of the carrier ${ }^{32}$.

The individuals cared by the PSF that reported alimentary diet had less chance of having worst quality of life. It is known that the adequacy of alimentary habits of diabetic patients, along with other cares, is essential for the maintenance of ideal glycemic control, so to avoid possible complications. According to recent report of the 
World Health Organization (OMS) on diet, nutrition and prevention of DCNT, the association between gain of weight, abdominal obesity, sedentary lifestyle and the development of type 2 diabetes mellitus is convincing ${ }^{33}$. Most part of type 2 diabetes patients, that represents $90 \%$ to $95 \%$ of the diabetes patients population, is overweight or obese ${ }^{3}$. However, new studies must be performed so to emphasize the direct impact of diet for diabetes on the quality of life of its carriers.

With exception to time of diagnosis and sex, the other variables that directly impacted in quality of life of diabetics are modifiable factors, reinforcing the importance of education in health on public services for the treatment of diabetes, and also the identification of those factors by health professionals, so to enable the patient in transforming his own attitude towards the disease ${ }^{34}$.

So, the recognition of these factors must be funded in conceptual models that allow identifying the health deviations of this population, being Orem's conceptual model one of the most utilized by nurses to diagnose patients with chronic diseases ${ }^{35}$. In this sense, the precise diagnose is elaborated to guide meaningful educational actions.

To Alves and Aerts ${ }^{36}$, for the education to have meaning to the learner, the knowledges on health must be debated with the patients so to, after this discussion, they can choose a healthier life and changes in their lifestyle. Besides, education in health must be instrumentalized, in its daily practice, with practical, simple, short strategies, of easy application and low cost that can be incorporated to the routine of the multidisci- plinary team in care to diabetic patient in referral at the public network ${ }^{37}$.

This study has some limitations. Due to being a cross-sectional study, it seeks interferences to causal factors, without, nevertheless, establishing a temporal relationship. The alimentary issue to diabetes may be understood through different perspectives, depending on the individual and according to what he believes is an adequate diet. In the city concerned, the Primary Health Care does not has a nutritionist on the team and the Specialized Health Care offers such service, but it is not capable of servicing all the demand, thus some cases are prioritized. On practice of physical activity, the nature and frequency of it was not a target in the questions, what may have generated different interpretations on the part of the interviewed.

This study contributes to point the factors that affect the quality of life of patients with type 2 diabetes cared in Basic and Special Health Care. It is concluded that with exception to the time of diagnosis and gender, other variables that influenced quality of life for diabetic were modifiable factors (value of glycated hemoglobin, adhesion to alimentary diet and practice of physical activity), evidencing that the education in health is a essential component on treating diabetes. Identifying these risk factors on the different attention levels in health enables the managers and professionals involved in handling of diabetes to reassess their public policies and services destined to the treatment of this pathology, so to qualify the attention points and assure an adequate assistance for those patients, qualifying the care line.

\section{Collaborations}

K Corrêa, GR Gouvêa, MAV Silva, RF Possobon, LFLN Barbosa, AC Pereira, LG Miranda and KL Cortellazzi participated equally in all stages of preparation of the article. 


\section{References}

1. Sartorelli DS, Franco LJ. Tendências do diabetes mellitus no Brasil: o papel da transição nutricional. Cad Saude Publica 2003; 19(Supl. 1):29-36.

2. International Diabetes Federation (IDF). Diretriz para o gerenciamento da glicose pós-prandial. [internet] 2013; [acessado 2013 mar 24]. Disponível em: http:// www.idf.org/webdata/docs/Portuguese\%20Brazilian_ GMPG\%20Final\%20150208.pdf

3. Sociedade Brasileira de Diabetes (SBD). [acessado 2014 fev 02]. Disponível em: http://www.diabetes.org.br/ sala-de-noticias/2116-sao-12-milhoes-de-diabeticosnobrasil

4. Francisco PMSB, Belon AP, Barros MBA, Carandina L, Alves MCGP, Goldbaum M, Cesar CLG. Diabetes auto-referido em idosos: prevalência, fatores associados e práticas de controle. Cad Saude Publica 2010; 26(1):175-184.

5. Edelman D, Olsen MK, Dudley TK, Harris AC, Oddone EZ. Impact of diabetes screening on quality of life. $D i$ abetes Care 2002; 25(6):1022-1026.

6. Chia L. The characteristics that associate with health related quality of life in patients with type-2 diabetes [tese]. Pittsburgh: University of Pittsburgh; 2007.

7. Paiva DCP, Bersusa AAS, Escuder MML. Avaliação da assistência ao paciente com diabetes e/ou hipertensão pelo Programa Saúde da Família do município de Francisco Morato, São Paulo, Brasil. Cad Saude Publica 2006; 22(2):377-385.

8. Brasil. Ministério da Saúde (MS). Secretaria de Políticas de Saúde. Departamento de Ações Programáticas Estratégicas. Plano de reorganização da atenção à hipertensão arterial e ao diabetes mellitus. Brasília: MS 2002 [acessado 19 jun 2012]. Disponível em: http:// bvsms.saude.gov.br/bvs/publicacoes/miolo2002.pdf

9. Toscano CM. As campanhas nacionais para detecção das doenças crônicas não transmissíveis: diabetes e hipertensão arterial. Cienc Saude Colet 2004; 9(4):885895.

10. Silva AM, Vargas AMD, Ferreira EF, Abreu MHNG. A integralidade da atenção em diabéticos com doença periodontal. Cien Saude Colet 2010; 15(4):2197-2206.

11. Instituto Brasileiro de Geografia. Rio de Janeiro: IBGE. [acessado 2013 mar 02]. Disponível em: http://cidades.ibge.gov.br/xtras/perfil.php?lang = ecodmun $=$ 353870esearch $=$ saopaulo| piracicaba

12. Cursio R, Lima MHM, Alexandre NMC. Instrumentos relacionados ao diabetes mellitus adaptados e validados para a cultura brasileira. Rev Eletrônica Enferm [internet]. 2011; [acessado 2012 maio 30] 13(2):331-337. Disponível em: http://www.fen.ufg.br/fen_revista/v13/ n2/pdf/v13n2a20.pdf

13. DCCT Research Group. Diabetes control and complications Trial (DCCT). Reliability and validity of a diabetes quality-of-life measure for the diabetes control and complications trial (DCCT). Diabetes Care [internet] 1988 out; [acessado 2013 abr 12] 11(9):725-32. Disponível em: http://care.diabetesjournals.org/content/11/9/725.full.pdf+html

14. Jacobson AM, De Groot M, Samson JA. The evaluation of two measures of quality of life in patients with type I and type II diabetes. Diabetes Care 1994; 17(4):267274
15. Correr CJ, Pantarolo R, Melchiors AC, Rossignoli P, Llimós FF, Radominski RB. Tradução para o português e validação do instrumento Diabetes Quality of Life Measure (DQOL-Brasil). Arq Bras Endocrinol Metabol 2008; 52(3):515-522.

16. Diabetes Federation. Diabetes atlas update 2012: regional and country factsheets [internet] 2012; [acessado 2012 nov 22]. Disponível em: http://www.idf. org/diabetes-atlas-update-2012-regional-countryfactsheets.

17. Gross JL, Silveiro SP, Camargo JL, Reichelt AJ, Azevedo MJ. Diabetes Melito: diagnóstico, classificação e avaliação do controle glicêmico. Arq Bras Endocrinol Metabol 2002; 46(1):16-26

18. Sumita NM, Andriolo A. Importância da hemoglobina glicada no controle do diabetes mellitus e na avaliação de risco das complicações crônicas. J Bras Patol Med Lab 2008; 44(3):169-174.

19. Malta DC, Merhy EE. O percurso da linha de cuidado sob a perspectiva das doenças crônicas não transmissíveis. Interface (Botucatu) 2010; 14(34):593-605.

20. Brasil. Ministério da Saúde (MS). Secretaria de Vigilância em Saúde. Vigitel Brasil 2011: Vigilância de Fatores de Risco e Proteção para Doenças Crônicas por Inquérito Telefônico. Brasília: MS; 2012. (Série G. Estatística e Informação em Saúde).

21. Mohr F, Pretto LM, Fontela PC, Winkelmann ER. Fatores de risco cardiovascular: comparação entre os gêneros em indivíduos com diabetes mellitus tipo 2. Rev Contexto Saúde 2011; 10(20):267-272.

22. Brasil. Ministério da Saúde (MS). Secretaria de Atenção à Saúde. Departamento de Atenção Básica. Estratégias para o cuidado da pessoa com doença crônica: diabetes mellitus. Brasília: MS; 2013. (Cadernos de Atenção Básica, n. 36)

23. Faria HTG, Rodrigues FF, Zanetti ML, Araújo MF, Damasceno MM. Fatores associados à adesão ao tratamento de pacientes com diabetes mellitus. Acta Paul Enferm 2013; 26(3):231-237.

24. Rubin RR, Peyrot M. Quality of life and diabetes. Diabetes Metab Res Rev 1999; 15 (3):205-218.

25. Pontieri FM, Bachion MM. Crenças de pacientes diabéticos acerca da terapia nutricional e sua influência na adesão ao tratamento. Cien Saude Colet 2010; 15(1):151-160.

26. Liao D, Asberry PJ, Shofer JB. Improvement of BMI, body composition, and body fat distribution with lifestyle modification in Japonese Americans with impaired glicose tolerance. Diabetes Care 2002; 25(9):1504-1510.

27. Bennett WL, Ouyang P, Wu AW, Barone BB, Stewart KJ. Fatness and Fitness: how do they influence health-related quality of life in type 2 diabetes mellitus? Health Qual Life Outcomes [internet] 2008; [acessado 2013 jun17] 6: 110. Disponível em: http://www.biomedcentral.com/content/pdf/1477-7525-6-110.pdf

28. Danielle TMC, Bruin VMS, Oliveira DSN, Pompeu CMR, Forti, AC. Associação entre atividade física, comorbidades, sintomas depressivos e qualidade de vida relacionada à saúde em diabéticos tipo 2. Arq Bras Endocrinol Metabol 2013 fev; 57(1):44-50. 
29. Penckofer S, Ferrans CE, Velsor-Friedrich B, Savoy S. The psychological impact of living with diabetes: women day-to-day experiences. Diabetes Educator 2007; 33(4):680-690.

30. Krug RR, Lopes MA, Mazo GZ. Barreiras e facilitadores para a prática da atividade física de longevas inativas fisicamente. Rev Bras Med Esporte 2015; 21(1):57-64.

31. Goddijn PPM, Bilo HJG, Feskens EJM, Groenier KH, Van Der Zee KI, De Jong BM. Longitudinal study on glycaemic control and quality of life in patients with type 2 diabetes mellitus referred for intensified control. Diabet Med 1999; 16(1):23-30.

32. Norris SL, Zhang X, Avenell A. Long-term non-pharmacologic weight loss interventions for adults with type 2 diabetes. Cochrane Database Syst Rev 2005; (2):CD004095.

33. World Health Organization. Food and Agriculture Organization. Joint WHO/FAO expert consultation. Diet, nutrition and the prevention of chronic diseases. Geneva: WHO/FAO; 2003.

34. Rodrigues FFL, Zanetti ML, Santos MA, Martins TA, Souza VD, Teixeira CRS. Conhecimento e atitudes: componentes para a educação em diabetes. Rev Lat Am Enfermagem [internet] 2009 jul-ago; [acessado 2014 fev 10] 17(4). Disponível em: http://www.scielo.br/pdf/ rlae/v17n4/pt_06.pdf

35. Orem DE. Nursing: concepts of practice. $3^{\text {rd }}$ Ed. New York: McGraw-Hill; 1985.

36. Alves GG, Aerts D. As práticas educativas em saúde e a Estratégia Saúde da Família. Cien Saude Colet 2011; 16(1):319-325.

37. Silva MAV, Gouvêa GR, Claro AFB, Agondi RF, Cortellazzi KL, Pereira AC, Meneghim MC, Mialhe FL. Impacto da ativação da intenção na prática da atividade física em diabéticos tipo II: ensaio clínico randomizado. Cien Saude Colet 2015; 20(3):875-886.

Article submitted 05/05/2015

Approved 10/05/2016

Final version submitted 12/05/2016 